\title{
Morphological and Volumetric Characteristics of Holstein-Gir Crossbred Calves' Stomachs Fed Diets Comprising Cheese Whey and Milk Powder
}

\author{
Maria Vivianne F. G. de Miranda ${ }^{1}$, Tiago da S. Teófilo ${ }^{1}$, Ana Paula P. de Assis ${ }^{1}$, Hélia Maria de S. Leite ${ }^{1}$, \\ Andrezza K. B. de Moura ${ }^{2}$, Vitor Lucas de L. Melo ${ }^{1}$, José Domingues F. Neto ${ }^{1}$ \& Patrícia de O. Lima ${ }^{1}$ \\ ${ }^{1}$ Department of Animal Sciences, Federal Rural University of the Semi-Arid, Mossoró, Brazil \\ ${ }^{2}$ Federal Institute of Education, Science and Technology of Pará, Breves, Brazil \\ Correspondence: Vitor Lucas de L. Melo, Department of Animal Sciences, Federal Rural University of the Semi- \\ Arid, Mossoró, Brazil. Tel: 55-84-9-8739-1917. E-mail: vitor_llm@hotmail.com
}

\author{
Received: March 5, $2021 \quad$ Accepted: March 28, $2021 \quad$ Online Published: March 29, 2021 \\ doi:10.5539/jsd.v14n2p179 URL: https://doi.org/10.5539/jsd.v14n2p179
}

\begin{abstract}
The objective of this study was to evaluate the effect of powdered cheese whey and milk powder as a substitute for whole milk on rumen development in calves up to 60 days of age. Twenty-one-week-old Holstein-Gir crossbred calves were randomized across four treatments and six replicates: LI: whole milk (Control); LP: milk powder; LPS1: 80\% milk powder $+20 \%$ cheese whey powder; LPS2: 60\% Milk Powder $+40 \%$ Cheese Whey Powder. The animals were slaughtered at 60 days of age. The consumption, weight of stomach and its compartments, ruminal papilla height, and rumen proliferative activity were measured. Dry matter intake, absolute and relative weights of the gastric compartments were similar. Significant differences were found in the development of rumen papillae and the mean height of the ventral sac was higher in the animals that received whole milk. There were no significant differences for cell proliferation rate in rumen papillae. It is suggested that feeding calves whey with powdered milk may be a viable alternative to the use of whole milk without harming dairy calves.
\end{abstract}

Keywords: cell proliferation, dairy byproduct, morphometry

\section{Introduction}

When ruminants are born, they have a small and nonfunctional aglandular portion of the stomach (rumen, reticulum, and omaso), being considered physiologically non-ruminant, and the rapid development of these compartments is associated with the diet type at the rearing phase (Khan et al. al., 2016). Thus, the capacity of all stomach compartments changes as calves age, with accelerated rumen growth and abomasal growth retraction. The major developmental changes occur in rumen after colonization by different types of microorganisms and development of the inner wall (papillae) (Carvalho et al., 2003). In ruminal conditions, food is fermented by the established facultative anaerobic or aerobic microorganisms, that supply necessary nutrients in the form of short chain fatty acids (SCFA) (Kamra, 2005).

The development of rumen in calves can directly affect the intake of feed, nutrient digestibility and overall growth. Even minor changes in the early feeding regime and nutrition can drastically influence rumen development, resulting in long-term effects on growth, health, and milk yields in adult cattle (Diao et al., 2019).

The ruminal epithelium performs many important functions and plays the key role in rumen development, including absorption, transportation, SCFA metabolism, and protection. The proliferation and growth of the rumen squamous epithelium promotes the growth of papillae length and width. Newborn calves have a smooth epithelium with no prominent papillae (Baldwin et al., 2004).

After born, the rumen development can be divided in three phases: preruminant phase (0-3 wk) in which animals are fed on milk, which bypasses the rumen through the esophageal groove; transition phase (3-8 wk); and ruminant phase (from $8 \mathrm{wk}$ ) in which ruminants are only fed solid diets (Lane et al., 2000). The artificially rearing suckling calves represents one of the most crucial steps in dairy production and may compromise the future life of the herd (Virgínio Júnior et al., 2016).

Substitutes such as cheese whey and milk powder can be used as alternative substances to whole milk, as they are 
by-products in the low-priced cheese industry and milk-powder factories (Miranda et al., 2019). The objective of this study was to evaluate the use of powdered cheese whey and milk powder as a substitute for whole milk in calf suckling up to 60 days of age on rumen development.

\section{Method}

\subsection{Animals, Diet Treatments, and Experimental Design}

Twenty-four Holstein-Gir crossbred male calves with the initial age of $5 \pm 3$ days, and the average weight of 35 $\mathrm{kg}$ were used. The animals were randomized across four groups (six calves each) across the following feeding treatments: LI: whole milk (Control); LP: milk powder; LPS1: $80 \%$ milk powder $+20 \%$ cheese whey powder; LPS2: $60 \%$ Milk Powder $+40 \%$ Cheese Whey Powder. All experimental procedures were approved by the Bioethics and Animal Use Committee of the Rural Federal University of Semi-Arid, under opinion No. 17/2011, case No. 23091.002083 / 2011-66.

All animals received colostrum after birth. At 2 days, the calves were fed four liters of whole milk twice a day (2 $\mathrm{L}$ each morning and afternoon) for 10 days. Prior to the beginning of the treatments, the adaptation of the animals to the diet treatments continued for ten days, when the tested diets were gradually replaced with whole milk ( $10 \%$ each day), to avoid gastrointestinal disorders. The experimental period was performed during the six weeks after the adaptation period. All animals were dewormed and received injectable ADE vitamin complex. Subsequently, they were kept in the confinement system in individual stalls covered with shade, where they had access to bran concentrate, Tifton hay (Cynodon sp.), and water ad libitum from birth to desalination. Dry matter intake (DMI) was calculated using the supply / surplus method, where the amount of feed offered was based on hay and concentrate from the previous day with added $10 \%$ surplus.

\subsection{Slaughter and Sampling Procedures}

Calves were slaughtered at 60 days of age after 16 hours of solid fasting and were subsequently weighed to determine the weight of the fasting slaughter. The animals were slaughtered in accordance with the current legislation (BRAZIL, 2000).

After slaughter, total weight of the stomach compartments as well as the individual compartments were recorded. Subsequently, all compartments were emptied and reweighed, thus obtaining the weight of the empty compartments and the weight of the stomach content. Organ and compartment weights were absolute values $(\mathrm{kg})$, relative to the function of empty body weight (\% EBW) and relative to the function of complete stomach weight $(\% \mathrm{SW})$.

\subsection{Histological Analyzes}

Tissue fragments of approximately one square centimeter $(1 \mathrm{~cm} 2)$ were sampled from four regions of the rumen: ruminal atrium, dorsal, blind dorsal, and ventral sacs. These fragments were fixed in $4 \%$ formalin for 24 hours and processed for paraffin embedding.

The slides were photographed in a photomicroscope (Olympus BX51®, Olympus Optical Co., Japan) equipped with the DP72 CCD digital camera. Subsequently, they were analyzed in the Image J Version $1.51 \mathrm{k}$ software, where the papillary heights of the ruminal atrium, dorsal, caudal, and ventral sacs were measured. Approximately 200 papillae were measured per animal, resulting in a total of 4,800 measurements.

Proliferative activity in tissues removed from the rumen was evaluated by counting Argyrophilic Nucleolus Organizing Regions (AgNOR). Tissue sections of $5.0 \mu \mathrm{m}$ were made from the four regions of the rumen, they were deparaffinized in xylol and ethanol (100\%), postfixed in absolute ethanol: acetic acid (3: 1) solution for 30 $\mathrm{min}$ at room temperature and rehydrated. For the silver impregnation procedure for AgNORs visualization, two solutions were prepared separately: $2 \%$ gelatin in $1 \%$ aqueous formic acid solution (solution A), and $50 \%$ silver nitrate aqueous solution (solution B). The staining solution was prepared immediately prior to the procedure by mixing solution A with solution B (1:2) in a light-protected vial. The sections were stained in the darkness at room temperature for 30 minutes, then washed with distilled water and the reaction was blocked with $5 \%$ aqueous sodium thiosulfate solution for 5 minutes at room temperature. The sections were dehydrated in a gradual series of xylol ethanol and mounted with Canadian balm.

For each slide 20 random areas were photographed, and in each area 50 cells were observed, with a total of 1,000 cells per animal. AgNORs were visualized as intranuclear dark spots in the ruminal mucosa epithelial cells. The cells were counted under light microscope, at 1,000x magnification, in a blind study manner to prevent bias in the results. 


\subsection{Statistical Analysis}

The total number of AgNOR per nucleus was mean \pm standard error. Data were grouped according to treatment and statistically analyzed by Tukey test at a significance level of $5 \%$. The rest of the data were subjected to analysis of variance and mean comparison test using the IBM-SPSS (IBM Statistics 20) statistical package. The effects of the treatments on each variable were compared by ANOVA, followed by a Tukey post-hoc test at $5 \%$ probability.

\section{Results}

We observed an increase in the consumption of solid foods over the weeks $(\mathrm{Y}=79.14+114.54 \mathrm{X} ; \mathrm{R} 2=0.93)$.

The intake of dry matter in this study did not differ statistically between the tested diet treatments $(P>0.05)$ (Table $1)$.

Table 1 . The average total dry matter intake of calves fed diet containing different amounts of powdered cheese whey and milk powder (g / calf / day)

\begin{tabular}{cccccccc}
\hline \multirow{2}{*}{ Week } & \multicolumn{9}{c}{ Liquid diet } & \multirow{2}{*}{ Mean } & CV & $P$-value \\
\cline { 2 - 5 } & WM & PM & WMCW1 & WMCW 2 & & & \\
\hline 1 & 643,48 & 577,28 & 603,83 & 671,68 & 623,55 & 12,28 & 0,37 \\
2 & 688,08 & 696,01 & 658,07 & 732,80 & 690,80 & 17,22 & 0,90 \\
3 & 768,42 & 800,23 & 741,73 & 768,25 & 769,59 & 17,46 & 0,96 \\
4 & 922,77 & 978,38 & 878,58 & 912,13 & 923,58 & 25,13 & 0,96 \\
5 & 1113,08 & 1171,23 & 1071,88 & 1166,88 & 1126,57 & 36,36 & 0,99 \\
6 & 1266,40 & 1416,19 & 1415,28 & 1295,04 & 1341,72 & 33,64 & 0,95 \\
DMI & 900,37 & 939,89 & 894,90 & 924,48 & 912,63 & 23,69 & 0,99 \\
\hline
\end{tabular}

Means with different letters on the lines are significant $(\mathrm{P}<0.05)$ by the Tukey test; DMI: Average total dry matter intake; WM: whole milk (control); PM: powdered milk; WMCW1: $80 \%$ powdered milk $+20 \%$ powdered cheese whey; WMCW 2: $60 \%$ powdered milk $+40 \%$ powdered cheese whey.

The absolute and relative weights of the gastric compartments did not show significant differences between the diet treatments $(\mathrm{P}>0.05)$, as well as the percentage participation of the gastric compartments, the total weight of the empty stomach and the contents of the 4 gastric compartments $(P>0.05)$ (Table 2). They are therefore consistent with the food intake data. 
Table 2. The absolute weight of empty stomach $(\mathrm{kg})$, relative as a function of empty body weight (\% PCVZ), relative as a function of total stomach weight (\% PE) and gastric compartment content (kg) of calves fed diets containing whey and milk powder

\begin{tabular}{|c|c|c|c|c|c|c|}
\hline \multirow{2}{*}{ Variable } & \multicolumn{4}{|c|}{ Liquid diet } & \multirow{2}{*}{ P-value } & \multirow{2}{*}{$\mathrm{CV}$} \\
\hline & WM & PM & WMCW1 & WMCW2 & & \\
\hline \multicolumn{7}{|c|}{ (kg) } \\
\hline Stomach & $1,41^{\mathrm{a}}$ & $1,41^{\mathrm{a}}$ & $1,58^{a}$ & $1,57^{\mathrm{a}}$ & 0,89 & 26,45 \\
\hline Rumen-reticulum & $0,86^{\mathrm{a}}$ & $0,94^{\mathrm{a}}$ & $1,04^{\mathrm{a}}$ & $1,00^{\mathrm{a}}$ & 0,76 & 26,19 \\
\hline Omasum & $0,16^{\mathrm{a}}$ & $0,17^{\mathrm{a}}$ & $0,20^{\mathrm{a}}$ & $0,21^{\mathrm{a}}$ & 0,87 & 42,16 \\
\hline Abomasum & $0,38^{\mathrm{a}}$ & $0,30^{\mathrm{a}}$ & $0,35^{\mathrm{a}}$ & $0,36^{\mathrm{a}}$ & 0,74 & 30,28 \\
\hline \multicolumn{7}{|c|}{$(\% \mathrm{PCVZ})$} \\
\hline Stomach & $2,82^{\mathrm{a}}$ & $3,19^{\mathrm{a}}$ & $3,31^{\mathrm{a}}$ & $3,43^{\mathrm{a}}$ & 0,46 & 18,94 \\
\hline Rumen-reticulum & $1,73^{\mathrm{a}}$ & $2,09^{\mathrm{a}}$ & $2,18^{\mathrm{a}}$ & $2,20^{\mathrm{a}}$ & 0,17 & 18,76 \\
\hline Omasum & $0,32^{\mathrm{a}}$ & $0,38^{\mathrm{a}}$ & $0,41^{\mathrm{a}}$ & $0,44^{\mathrm{a}}$ & 0,61 & 34,20 \\
\hline Abomasum & $0,76^{\mathrm{a}}$ & $0,71^{\mathrm{a}}$ & $0,72^{\mathrm{a}}$ & $0,80^{\mathrm{a}}$ & 0,10 & 28,76 \\
\hline \multicolumn{7}{|c|}{$(\% \mathrm{SW})$} \\
\hline Rumen-reticulum & $61,19^{\mathrm{a}}$ & $66,77^{\mathrm{a}}$ & $66,01^{\mathrm{a}}$ & $64,26^{\mathrm{a}}$ & 0,43 & 8,75 \\
\hline Omasum & $11,73^{\mathrm{a}}$ & $11,80^{\mathrm{a}}$ & $12,51^{\mathrm{a}}$ & $11,94^{\mathrm{a}}$ & 0,99 & 24,54 \\
\hline Abomasum & $27,08^{\mathrm{a}}$ & $21,35^{\mathrm{a}}$ & $21,48^{a}$ & $23,80^{\mathrm{a}}$ & 0,26 & 21,75 \\
\hline \multicolumn{7}{|c|}{ Compartment content $(\mathrm{kg})$} \\
\hline Stomach & $4,73^{\mathrm{a}}$ & $5,68^{\mathrm{a}}$ & $6,63^{\mathrm{a}}$ & $6,69^{\mathrm{a}}$ & 0,50 & 37,63 \\
\hline Rumen-reticulum & $2,67^{\mathrm{a}}$ & $3,73^{\mathrm{a}}$ & $4,39^{\mathrm{a}}$ & $4,37^{\mathrm{a}}$ & 0,39 & 47,28 \\
\hline Omasum & $0,07^{\mathrm{a}}$ & $0,10^{\mathrm{a}}$ & $0,10^{\mathrm{a}}$ & $0,10^{\mathrm{a}}$ & 0,86 & 69,71 \\
\hline Abomasum & $0,58^{\mathrm{a}}$ & $0,44^{\mathrm{a}}$ & $0,56^{\mathrm{a}}$ & $0,66^{\mathrm{a}}$ & 0,83 & 54,00 \\
\hline
\end{tabular}

Means with different letters on the lines are significant $(\mathrm{P}<0.05)$ by the Tukey test; WM: whole milk (control); PM: powdered milk; WMCW1: $80 \%$ powdered milk $+20 \%$ powdered cheese whey; WMCW $2: 60 \%$ powdered milk $+40 \%$ powdered cheese whey.

In the regions of the rumen atrium, dorsal and caudal sacs, the growth of rumen papillae was not statistically different $(\mathrm{P}>0.05)$ between the tested diets (Table 3$)$.

Table 3. The mean height $(\mathrm{mm})$ of rumen papillae in calves submitted to diets containing whey and milk powder.

\begin{tabular}{|c|c|c|c|c|c|c|}
\hline \multirow{2}{*}{ Variable } & \multicolumn{4}{|c|}{ Liquid diet } & \multirow[t]{2}{*}{$P$-value } & \multirow[t]{2}{*}{$\mathrm{CV}$} \\
\hline & WM & MP & MPCW1 & MPCW2 & & \\
\hline Rumen atrium & $1,47^{\mathrm{a}}$ & $1,42^{\mathrm{a}}$ & $1,39^{\mathrm{a}}$ & $1,09^{\mathrm{a}}$ & 0,77 & 0,03 \\
\hline Dorsal sac & $0,48^{\mathrm{a}}$ & $0,38^{\mathrm{a}}$ & $0,49^{\mathrm{a}}$ & $0,54^{\mathrm{a}}$ & 0,79 & 0,04 \\
\hline Caudal sac & $1,56^{\mathrm{a}}$ & $1,25^{\mathrm{a}}$ & $1,28^{\mathrm{a}}$ & $1,38^{\mathrm{a}}$ & 0,92 & 0,05 \\
\hline Ventral sac & $6,72^{\mathrm{a}}$ & $4,63^{\mathrm{b}}$ & $4,69^{\mathrm{b}}$ & $3,91^{\mathrm{b}}$ & $<0,001$ & 0,02 \\
\hline
\end{tabular}

Means with different letters on the lines are significant $(\mathrm{P}<0.05)$ by the Tukey test; WM: whole milk (control); PM: powdered milk; WMCW1: $80 \%$ powdered milk $+20 \%$ powdered cheese whey; WMCW 2: $60 \%$ powdered milk $+40 \%$ powdered cheese whey. 
The morphology of ventral rumen papillae by HE (Hematoxylin-eosin) staining method is shown in Figure 1.

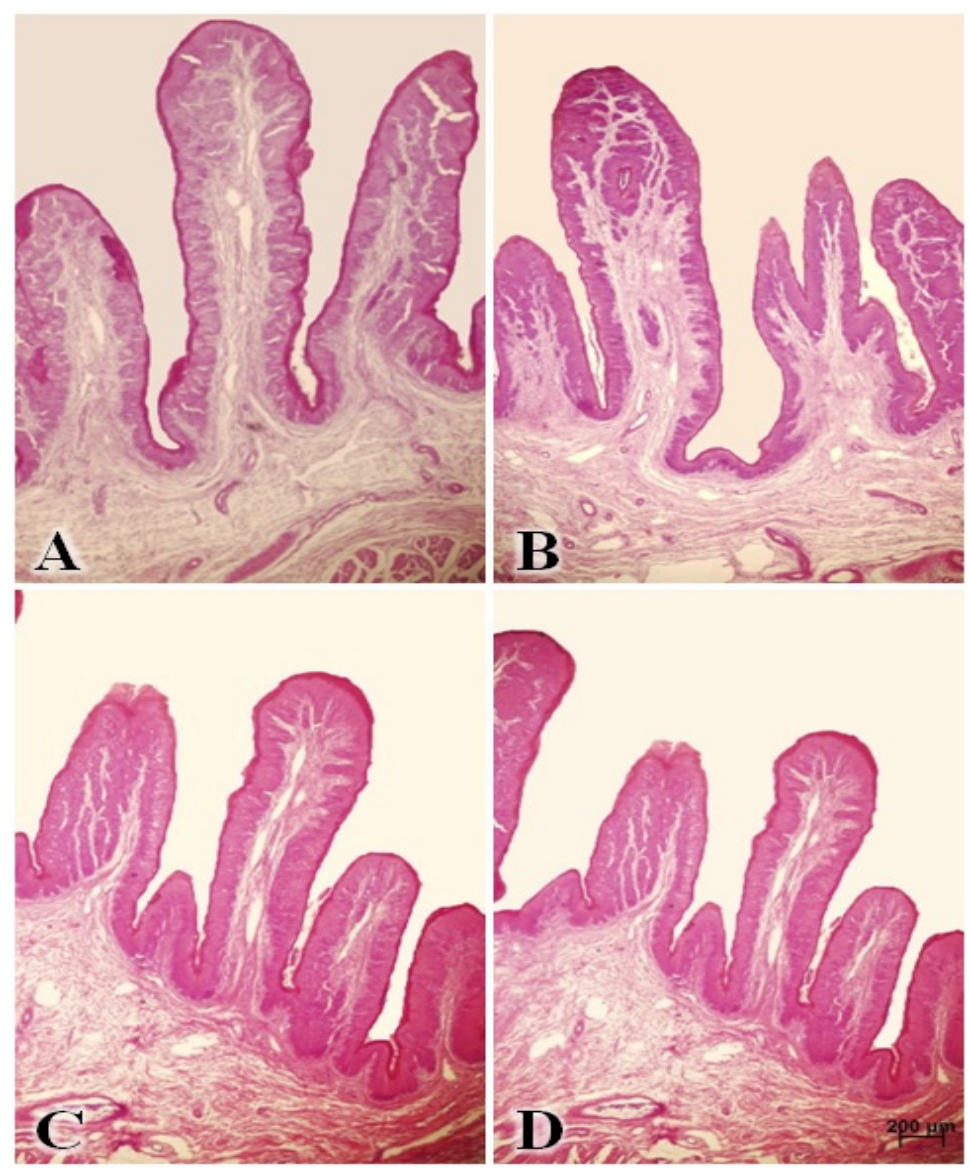

Figure 1. Longitudinal histological sections of the ventral rumen region of HE-stained calves (40X). Ventral papillae of calves receiving the diet treatments: A - whole milk (control); B - PM: powdered milk; C - WMCW1: $80 \%$ powdered milk $+20 \%$ powdered cheese whey; $\mathbf{D}-\mathrm{WMCW} 2: 60 \%$ powdered milk $+40 \%$ powdered cheese whey

The substitutes did not affect the production of argyrophil proteins in the observed cells, regardless of the diet offered to the animals (Table 4).

Table 4. AgNOR / nucleus count in epithelial cells of calves' ruminal ventral papillae receiving diets containing powdered cheese whey and milk powder

\begin{tabular}{|c|c|c|c|c|c|c|c|}
\hline \multirow{2}{*}{ Variable } & \multicolumn{4}{|c|}{ Liquid diet } & \multirow{2}{*}{$\mathrm{CV} \%$} & \multirow{2}{*}{$\begin{array}{c}\mathrm{P}- \\
\text { value }\end{array}$} & \multirow{2}{*}{ SEM } \\
\hline & WM & MP & MPCW1 & MPCW2 & & & \\
\hline \multicolumn{8}{|c|}{ Ventral region } \\
\hline Base & $2,37^{\mathrm{a}}$ & $2,67^{\mathrm{a}}$ & $2,48^{\mathrm{a}}$ & $2,10^{\mathrm{a}}$ & 19,22 & 0,54 & 0,11 \\
\hline Top & $2,32^{\mathrm{a}}$ & $2,51^{\mathrm{a}}$ & $2,45^{\mathrm{a}}$ & $2,14^{\mathrm{a}}$ & 18,14 & 0,48 & 0,12 \\
\hline
\end{tabular}

Means with different letters on the lines are significant $(\mathrm{P}<0.05)$ by the Tukey test; WM: whole milk (control); PM: powdered milk; WMCW1: $80 \%$ powdered milk $+20 \%$ powdered cheese whey; WMCW 2: $60 \%$ powdered milk $+40 \%$ powdered cheese whey.

The morphology of the rumen visualized by the histochemical silver staining method (AgNOR), shows the dark granule nucleus organizing regions (NOR) distributed in the epithelial cell nucleus (Figure 2). 


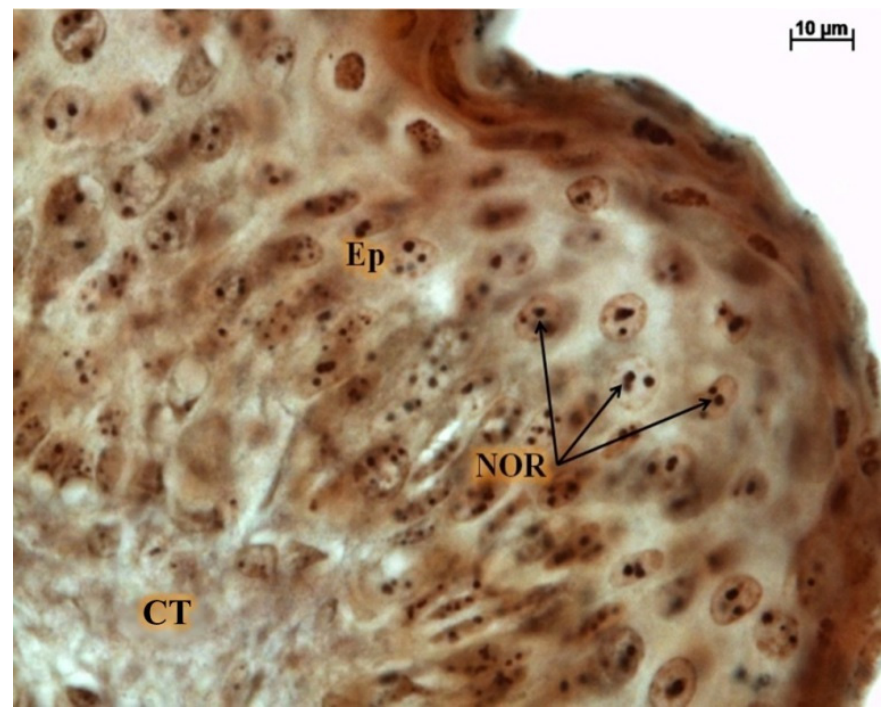

Figure 2. Ventral region of calf rumen: silver staining technique (AgNOR). The black spots on the nuclei are the nucleolus organizing regions (NORs), at 100x magnification. CT is connective tissue, Ep - epithelium

\section{Discussion}

In relation to consumption of solid foods, Costa et al. (2007) report that in the calf's first weeks of life the average daily intake of concentrate was low, as all of its nutritional requirements were met by the milk supply, and this consumption tends to increase over the weeks with increasing nutrition requirements with growth. According to Quigley and Bernard (1996), concentrate consumption increases rapidly between the third and sixth weeks of life, with a decrease over the next four to six weeks.

The results for intake of dry matter in this study were similar to the results found by Miranda et al. (2019), researched with calves fed cheese whey. Along with the liquid diet, the animals received hay and concentrate, thereby having access to a greater supply of energy and protein, possibly stimulating the ruminal functionality, the production of short chain fatty acids and, consequently, the development of the rumen papillae.

According to Lima et al. (2011) calves fed substitute diets generally do not perform better than those fed with whole milk or dairy substitutes. It appears that the animal development is not impaired, because the weight gain may be more significant in the next phase, i.e., after desalination.

About the absolute and relative weights of the gastric compartments as well as the percentage participation of the gastric compartments, Azevedo et al. (2014), researched Dutch calves kept in different suckling systems, and found averages of $1.12 \mathrm{~kg}$ for empty rumen weight, $0.34 \mathrm{~kg}$ for empty abomasum weight and $0.24 \mathrm{~kg}$ for empty omasum weight, values similar to those found in our study. When calves are born they have a poorly developed reticulumrumen, representing around $30 \%$ of the four compartments, and this organ rapidly develops upon changes in the diet, when the animal consumes solid food (Costa et al., 2008).

According to Mancio et al. (2005), the size of the rumen is related to its functional capacity, therefore, the weight increase of this organ may demonstrate a transformation in the functional structure. The greater development of the rumen occurs due to the presence of solid foods, providing greater ruminal motility, epithelial and muscular development, besides the production of volatile fatty acids (Anderson et al., 1987). This growth depends on the amount of milk consumed during lactation and forage intake, and therefore the similarity observed in the development of stomach compartments is possibly related to similar consumption of solid foods (Table 1).

Calves showed a normal stomach development, as there were no statistically significant differences between the diet treatments in absolute and percentage weights, and the relation to empty body weight or stomach weight. However, it is necessary to ensure that diets do not negatively affect the metabolism of animals and it is important to investigate them at the histological level.

The animals that received the control diet $(100 \%$ whole milk) had a higher papilla development $(\mathrm{P}<0.05)$ in the ventral sac. The addition of sodium butyrate to calf diets resulted to the average ventral papillae length of $3.73 \mathrm{~mm}$ in Holstein calves at 70 days of age (Ferreira et al., 2009). Huber et al. (1969) advocate that the normal height of the papillae of 8-week-old calves suckled with whole milk should be between 5 and $7 \mathrm{~mm}$. Zitnam et al. (2005) 
found that papillae height in the ruminal atrium region was $1.89 \mathrm{~mm}$ and $1.25 \mathrm{~mm}$ for the ventral sac region of calves at 40 days of age. Costa et al. (2008) tested with butyrate, propionate and lactate induction on the rumen mucosa of calves slaughtered at 90 days found that caudal papillae height was $1.32 \mathrm{~mm}$, similar to those found in our experiment.

60-day-old Holstein calves provided with whole milk, and Lactal ${ }^{\circledR}$ (whey and milk replacement) and Destetor ${ }^{\circledR}$ replacement, had shorter rumen papillae in the group that consumed substitutes for whole milk treatment (Silva et al., 2004). These authors suggest that the lower concentrate intake in substitute-based treatments, indicates that most of the ingested dry matter comes from substitutes, and that poor dry matter substitutes will result in low papilla development. Diao et al. (2019) mention that it is the concentrate that provides formation of the rumen papillae, which have the property of considerably increasing the absorption surface of the organ.

The ventral region of the rumen has a greater contact with the food, due to high papillae density. As the food particles break down, they enter deeper regions into direct contact with the mucosa of the ventral sac. Short chain fatty acids (acetic, butyric, and propionic acids) are responsible for the development of rumen papillae. However, not every absorptive surface of the rumen performs a role of digestion. For example, most of the ruminal dorsal sac meets the rumen fluid short chain fatty acids only during rumen movements (Daniel et al., 2006), which explains why the dorsal sac has lower values of papillae development.

About the papillary development, in this experiment, all animals fed with alternative diets had a lower papillary development than suggested in the literature, and this may be due to the low amount (7\%) of dry matter in the composition of cheese whey (Liziere and Campos, 2006). In addition, it is plausible that some cheese whey was not fermented due to high liquid turnover and was digested post-ruminally. Owing to the complete absence of casein in whey, it does not coagulate in the abomasum, and this may lead to the rapid arrival of large amounts of nutrients in the small intestine after feeding, which may lead to overload of the digestive system as a whole. According to Church (1993), the abomasum wall tension and the high concentrations of fat, glucose, and amino acids that were observed when the clot formed, slowed down the gastric emptying process. With the replacement of whole milk by whey and the absence of coagulation in the abomasum, greater amount of this protein will reach the digestive site, may overload it, and reduce the efficacy of liquid diet.

As there was no difference in dry matter intake between the tested diets, it is plausible that animals that received diets containing whey had access to a smaller amount of dry matter, which may have interfered with the fermentation process, the production of AVG and, consequently, the development of the rumen papillae.

To assess the absorption surface area of the rumen epithelium, in addition to microscopic measurements such as ruminal papilla size measurement, the mitotic index has been used to measure the proliferative capacity of the ruminal epithelium. There was a similar pattern of cell proliferative activity in the papillae, regardless of the liquid diet provided $(\mathrm{P}>0.05)$.

The development of rumen papillae results from the difference between proliferation rates and cell death. Cell proliferation can be visualized by histochemical staining, such as the AgNORs method. Silver staining of nucleolus organizing regions (NORs) is characterized by marking ribosomal ribonucleic acid-bound proteins, assessing proliferation in normal or neoplastic cells (Chacur et al., 2015). Their count can be used to assess the rate of cell proliferation as these proteins tend to accumulate in mitotically active cells, while their expression in resting cells is low (Sirri et al., 2000).

Cell proliferation is essential for maintaining the integrity of the normal gastrointestinal mucosa, with cells constantly entering the cycles of replication, maturation, and apoptosis.

Resende Junior et al. (2006), observed that a lower frequency in concentrate feeding resulted in higher mitotic index of the basal layer of the ruminal epithelium. However, the greater cell division was not reflected in an increase in the microscopic dimensions of the rumen papillae. In this study, although the animals that consumed the whole milk (LI) diet presented taller ruminal papillae in the ventral region, the mitotic index was similar for all diets tested. Ruminal disease may respond to dietary changes; however, this may not be the only element analyzed to determine microscopic enlargement of rumen papillae.

Moreover, the technique used to evaluate the mitotic index in this work is an indirect way of estimating cell division (mitosis), as silver-labeled substances are argyrophilic proteins that, may be used in cell multiplication and the maintenance of cytoplasmic organelles within cells. Thus, despite the same argyrophilic protein production rates in all treatments, animals fed diets based on whey and powdered milk possibly did not target the synthesis of these proteins for cell division, but probably for the maintenance of cytoplasmic organelles, reflected in less developed papillae in the ventral region of the rumen of these animals. 
In the histological sections, the number of argyrophilic proteins counted in the calf rumen ventral cells showed a homogeneous distribution in the microscopic fields.

Although we imply that the AgNOR technique could indicate cell proliferation, no existing studies investigated this. We therefore suggest that more studies are needed to investigate this further. It is noteworthy that our findings may serve as a basis for future studies in the bovine species.

The diet with cheese whey and milk powder did not affect dry matter intake, stomach weight or cell proliferation rate in rumen papillae, although it negatively affected papilla size in the ventral region of the rumen.

\section{References}

Anderson, K. L., Nagaraja, T. G., \& Morrill, J. L. (1987). Ruminal metabolic development in calves weaned conventionally or early. Journal of Dairy Science, 70(5), 1000-1005. https://doi.org/10.3168/jds.S00220302(87)80105-4

Azevedo, R. A., Rufino, S. R., Cruz, M. S., Costa, S. F., Oliveira, N. J., Coelho, S. G., ... Geraseev, L. C. (2014). Desenvolvimento de bezerros leiteiros alimentados com silagem de leite de transição: I-Trato digestivo. Arquivo Brasileiro de Medicina Veterinária e Zootecnia, 66(2)489-496. https://doi.org/10.1590/167841626564

Baldwin, R. L., McLeod, K. R., Klotz, J. L., \& Heitmann, R. N. (2004) Rumen development, intestinal growth and hepatic metabolism in the pre- and postweaning ruminant. Journal of Dairy Science, 87(Suppl. E), E55-E65. https://doi.org/10.3168/jds.S0022-0302(04)70061-2

Carvalho, P. A., Bonnecarrère Sanchez, L. M., Viégas, J., Velho, J. P., Jauris, G. C., \& Rodrigues, M. B. (2003). Componentes do peso vivo e órgãos viscerais de bezerros machos de origem leiteira ao nascimento, 50 e 110 dias de vida. Revista Brasileira de Zootecnia, 32(6), 1469-1475. https://doi.org/10.1590/S151635982003000600022

Castro, A. L. M., Campos, W. E., Mancio, A. B., Pereira, J. C., \& Cecon, P. R. (2004). Desempenho e rendimento de carcaça de bezerros alimentados com colostro fermentado, associado ao óleo de soja e zeranol. Arquivo Brasileiro de Medicina Veterinária e Zootecnia, 56(2), 193-201. https://doi.org/10.1590/S010209352004000200009

Chacur, M. G. M., Ibrahim, D. B., Arrebola, T. A. H., Sanches, O. C., Giuffrida, R., Oba, E., \& Ramos, A. D. A. (2015). Avaliação da técnica de coloração AgNOR em testículos de ovinos. Arquivo Brasileiro de Medicina Veterinária e Zootecnia, 67(2), 447-454. https://doi.org/10.1590/1678-6695

Church, D. C. (1993). Digestion, metabolism and nutrient needs in preruminantes. In: The ruminant animal digestive physiology and nutrition. Oregon: Metropolitan Printing. p.401-420.

Costa, S. F. et al. (2008). Alterações morfológicas induzidas por butirato, propionato e lactato sobre a mucosa ruminal e a epiderme de bezerros: I Aspectos histológicos. Arquivo Brasileiro de Medicina Veterinária e Zootecnia, 60(1), 1-9. https://doi.org/10.1590/S0102-09352008000100001

Costa, T. C., Coelho, S. G., Fontes, F. A. P. V., Carvalho, A. U., Lana, A. M. Q., Ferreira, M. I. C., ... Saturnino, H. M. (2007). Consumo de mistura mineral e desempenho de bezerros alimentados com sucedâneos do leite. Arquivo Brasileiro de Medicina Veterinária e Zootecnia, 59(3), 749-758. https://doi.org/10.1590/S010209352007000300029

Daniel, J. L. P., Júnior, J. C. R., \& Cruz, F. J. (2006). Participação do ruminoretículo e omaso na superfície absortiva total do proventrículo de bovinos. Brazilian Journal of Veterinary Research and Animal Science, 43(5), 688694. https://doi.org/10.11606/issn.1678-4456.bjvras.2006.26579

Diao, Q., Zhang, R., \& Fu, T. (2019). Review of Strategies to Promote Rumen Development in Calves. Animals, 9(8), 490. https://doi.org/10.3390/ani9080490

Ferreira, L. S., Bittar, C. M. M., Santos, V. P. D., Mattos, W. R. S., \& Pires, A. V. (2009). Efeito da adição de butirato de sódio, propionato de cálcio ou monensina sódica no concentrado inicial sobre parâmetros ruminais e de desenvolvimento do rúmen de bezerros leiteiros. Revista Brasileira de Zootecnia, 38(11), 2238-2246. https://doi.org/10.1590/S1516-35982009001100025

Huber, J. T. (1969). Development of the digestive and metabolic apparatus of the calf. Journal of Dairy Science, 52(8), 1303-1315. https://doi.org/10.3168/jds.S0022-0302(69)86744-5

Kamra, D. N. (2005). Rumen microbial ecosystem. Current Science, 89(1), 124-135. 
Khan, M. A., Bach, A., Weary, D. M., \& Von Keyserlingk, M. A. G. (2016). Invited review: Transitioning from milk to solid feed in dairy heifers. Journal of Dairy science, 99(2), 885-902. https://doi.org/10.3168/jds.20159975

Lane, M. A., Baldwin, R. T., \& Jesse, B. W. (2000). Sheep rumen metabolic development in response to age and dietary treatments. Journal of Animal Science, 78(7), 1990-1996. https://doi.org/10.2527/2000.7871990x

Lima, R. N. D., de Oliveira Lima, P., Duarte Cândido, M. J., Rufino Moreira, R. H., \& da Silva Aquino, R. M. (2011). Avaliação econômica de dietas líquidas à base de soro de queijo in natura para bezerros. Revista $\begin{array}{llllll}\text { Brasileira de Saúde e Produção Animal, } & 12(1), & \text { 14-21. }\end{array}$ http://www.rbspa.ufba.br/index.php/rbspa/article/view/1895/1074

Mancio, A. B., Goes, R. H. D. T., Barros, E. E. L. D., Menin, E., Cecon, P. R., \& Silva, A. T. S. D. (2005). Desempenho produtivo de cabritos alimentados com diferentes dietas líquidas, associadas com promotor de crescimento. Revista Brasileira de Zootecnia, 34(4), 1305-1313. http://dx.doi.org/10.1590/S151635982005000400027

Miranda, M. V. F. G. D., Morais, M. R. P. T. D., Lima, R. N. D., Leite, H. M. D. S., Assis, A. P. P. D., Teófilo, T. D. S., ... Lima, P. D. O. (2019). Performance and development of gastric compartments of calves fed with cheese whey and transition milk. Ciência Rural, 49(9), 1-8. https://doi.org/10.1590/0103-8478cr20190308

Quigley III, J. D., \& Bernard, J. K. (1996). Milk replacers with or without animal plasma for dairy calves. Journal of dairy science, 79(10), 1881-1884. https://doi.org/10.3168/jds.S0022-0302(96)76556-6

Resende Júnior, J. C., Pereira, M. N., Bôer, H., \& Tamminga, S. (2006). Comparison of techniques to determine the clearance of ruminal volatile fatty acids. Journal of dairy science, 89(8), 3096-3106. https://doi.org/10.3168/jds.S0022-0302(06)72584-X

Silva, T. M., de Oliveira, M. D. S., Artoni, S. M. B., \& da Cruz, C. (2004). Desenvolvimento alométrico do trato gastrintestinal de bezerros da raça holandesa alimentados com diferentes dietas líquidas durante o aleitamento. Acta Scientiarum. Animal Sciences, 26(4), 493-499. https://doi.org/10.4025/actascianimsci.v26i4.1729

Sirri, V., Roussel, P., \& Hernandez-Verdun, D. (2000). The AgNOR proteins: qualitative and quantitative changes during the cell cycle. Micron, 31(2), 121-126. https://doi.org/10.1016/s0968-4328(99)00068-2

Virgínio Júnior, G. F., Azevedo, R. A., Ornelas, L. T. C., Oliveira, N. J. F., Geraseev, L. C., \& Duarte E. R. (2016) Caracterização físico-química e microbiológica do fluido ruminal e do conteúdo gastrointestinal de bezerros holandeses em aleitamento artificial convencional ou fracionado. Acta Veterinaria Brasilica, 10(4), 305-313. https://doi.org/10.21708/avb.2016.10.4.5551

Zitnan, R., Kuhla, S., Sanftleben, P., Bilska, A., Schneider, F., Zupcanova, M., \& Voigt, J. (2005). Diet induced ruminal papillae development in neonatal calves not correlating with rumen butyrate. Veterinarni MedicinaPraha, 50(11), 472. https://doi.org/10.17221/5651-VETMED

\section{Copyrights}

Copyright for this article is retained by the author(s), with first publication rights granted to the journal.

This is an open-access article distributed under the terms and conditions of the Creative Commons Attribution license (http://creativecommons.org/licenses/by/4.0/). 